\title{
National Exclusion, Local Inclusion: Examining the Disconnect between National Immigration Policies and Local Integration Policies
}

Exclusion nationale, inclusion locale: déconnexion entre politiques nationales d'immigration et politiques locales d'intégration

Exclusión nacional, inclusión local: Desconexión entre políticas nacionales de inmigración y políticas locales de integración

\section{Stephen-Robert Nagy}

\section{(2) OpenEdition}

\section{Journals}

Édition électronique

URL : https://journals.openedition.org/remi/4833

DOI : 10.4000/remi.4833

ISSN : $1777-5418$

Éditeur

Université de Poitiers

Édition imprimée

Date de publication : 1 décembre 2008

Pagination : 31-51

ISBN : 978-2-911627-50-7

ISSN : 0765-0752

\section{Référence électronique}

Stephen-Robert Nagy, « National Exclusion, Local Inclusion: Examining the Disconnect between National Immigration Policies and Local Integration Policies », Revue européenne des migrations internationales [En ligne], vol. 24 - n³ | 2008, mis en ligne le 01 décembre 2011, consulté le 14 avril 2022. URL : http://journals.openedition.org/remi/4833; DOI : https://doi.org/10.4000/remi.4833 


\title{
National Exclusion, Local Inclusion: Examining the Disconnect between National Immigration Policies and Local Integration Policies
}

\author{
Stephen Robert NAGY*
}

Immigration and integration of foreigners is typically inextricably linked with national government immigration policy. Ordinarily, national governments revise and adjust immigration policies based on projected economic and social need. (Usui, 2006) Local governments on the other hand are rarely, if ever seen as important actors with regards to immigration. Nevertheless, local governments are important government institutions once immigrants and migrant workers settle into their respective municipalities. Japan is no exception to this rule. In fact, owing to stipulations in Local Government Law; municipalities are the governmental institutions that bear the responsibility for all of their residents, including foreigners. (Komai, 2001: 119) This role is exasperated because the Japanese government has an immigration policy that could at best be described as closed and at worst discriminatory, inherently vacuous in its integrative policies that help foreign migrants settle smoothly within the borders of Japan. In contrast to this exclusionary policy and the reality that the numbers of foreigners are increasing year by year, ${ }^{1}$ local governments in Japan are in the process of creating more inclusive municipalities both out of legal obligation and out of need.

* Research Associate, Waseda University, Japan.

1 See Ministry of Justice Homepage for a complete explanation of the Immigration and Refugee Recognition Act: http://www.moj.go.jp/ENGLISH/IB/STANDARD/standard01.html (Accessed November 15 $\left.{ }^{\text {th }}, 2005\right)$. Also see: Japan Statistics Bureau Homepage for a break down in foreigner population growth: http://www.stat.go.jp/data/kokusei/2000/gaikoku/00/01.htm (Accessed January $15^{\text {th }}, 2006$ ). 
Even still, there continues to be disconnect between national immigration policies and local integration policies in Japan as of June 2006. The origins of this disconnect lie in the proximity to local residents to local governments. Moreover, the lack of correlation between immigration policy at the national level and economic need, the association of foreign residents with rising crime rates, and increased social instability as well as arguments revolving around the incompatibility of foreign peoples owing to Japan's homogeneity and lack of a history of accepting immigrants. This paper will examine how proximity to residents has compelled local governments to grab the horse by the reins, planning and implementing integration policies for foreigners under the rubric of "Internationalisation" and highlight the continued disconnect between immigration policies and economic need. The first section of this paper will examine national government policy vis-à-vis immigration by taking a closer look at recent recommendations for immigration policy reform and subsequently discusses arguments that continue to be used against immigration, namely, the relationship between increased crime and the number of foreigners, homogeneity and social instability and finally that Japan lacks a history of accepting immigrants.?The second section of this paper will then examine local government policy vis-à-vis foreigners. This analysis will explain why local governments are creating integration policies by highlight some of the influential forces driving the development of integration policy by local governments.

\section{NATIONAL GOVERNMENT POLICY}

\section{Report on the Future Acceptance of Foreigners}

In June 2006, the Vice Minister of Justice's research group called the "The Future of the Acceptance of Foreigners Project" published a report entitled the "Report on the Future Acceptance of Foreigners." The report summarised the most pressing issues regarding the future of Japanese society, in particular highlighting that Japan's future economic vitality and world standing is inextricably linked to a troika of trends: its greying population, declining birth rate and a recalcitrant immigration policy that needs to be revised to meet the future demands of Japanese society. ${ }^{2}$ The basic recommendations of the report included: ${ }^{3}$

(1) The number of foreigners accepted into Japan as migrant workers should increase to represent 3\% of the total population in Japan (Excluding Special Permanent Residents).

2 The Economist, January $7^{\text {th }}-13^{\text {th }} 2005$, pp. 29-30; The Economist, August $21^{\text {st }}-27^{\text {th }} 2005$. Also see: Bunkachou (Agency for Cultural Affairs) (2003) "Kongo no Kokusai Bunka Kouryu no Suishin ni tsuite" (Report on the future of International Cultural Exchange), Tokyo, Bunkachou (Agency of Cultural Affairs).

3 Houmusho (Ministry of Justice) (2006) Kongo no Gaikokujin no Ukeire ni Tsuite (Report on the Future Acceptance of Foreigners), Tokyo, Houmusho (Ministry of Justice) http://www.moj.go.jp/NYUKAN/nyukan51.html (Accessed June 30 ${ }^{\text {th }}, 2006$ ). 
(2) Japan needs to increase the number of short term foreigner visitors as well as revise its higher education system in order to promote exchanges with other countries at the human level. As part of this objective, Japan should expand its working holiday system, which is aimed at international students, and immigration procedures should be simplified as to promote more exchanges between Korea, the United States as well as other countries and Japan.

(3) Increase the quality of foreigner workers being admitted to Japan.

(4) Expanding the number of foreigners in Japan by creating a system to better manage resident foreigners.

(5) The acceptance of foreigners should occur in concert with obligatory contributions for national health care and other social welfare systems with social costs being partially subsidised.

(6) Education for the children of foreigners must be made to be mandatory in the same manner that it is obligatory for Japanese citizens to enhance the quality of life of foreigners living in Japan.

(7) The Japanese government needs to consider the demographic diversity of the resident foreigners so that they can contribute to the pluralism within Japan without disrupting Japanese society.

(8) Rationalise and make the immigration procedures more efficient.

Comprehensive and pragmatic, these basic recommendations are supported by concrete measures to ensure their realisation. Specifically, requirements for language proficiency of foreign migrants, a relaxation of immigration procedures among countries that have an bilateral agreements with Japan that have provided language training, the creation of a new system for accepting foreign workers that facilitates the visa application process in industries were special skills are needed, and increasing the diversity and variety in Japanese society.

Importantly, this report draws attention to the fact that past immigration policy revisions which resulted in a large influx of Nikkeijin ${ }^{4}$ are no longer acceptable. Specifically, the report plainly states that blood relations as prerequisites for legal entry into Japan are not in Japan's best interests. Rather, skills, knowledge and technical expertise are to be the yard stick in which visa applications are accepted or rejected. Another crucial recommendation of the report is the Japanese language proficiency. Foreign workers are expected to learn Japanese in order to renew their visas.

In addition to the above recommendations, the report recommends that the procedures for permanent resident status and naturalisation be simplified for those foreign residents who are contributing to Japanese society. Part of this simplification process includes creating a more pluralistic society based on a careful consideration of the diversity of foreigners being accepted. While simplifying the procedures for

4 "Nikkeijin" is a person of Japanese ancestry and is most commonly used with reference to South Americans of Japanese ancestry. 
receiving permanent residence and naturalising, the report also recommends that the process for naturalisation be stricter except for long-term residents, also sometimes called Old Comers ${ }^{5}$. Moreover, simplification of naturalisation and procedures for obtaining permanent residence encourages more and a larger variety of foreigners to apply to eventually become permanent fixtures of Japanese society.

Above and beyond the economic benefits of working in Japan, part of encouraging foreign migrant workers to come and work in Japan, contributing to Japan and living as productive, responsible and neighbourly residents is providing for the basic lifestyle requirements of foreign residents. As part of this report's recommendations, it encourages the government to guarantee basic rights of all foreign workers, recommends that foreign workers receive the same social welfare benefits as Japanese residents and that the children of foreign workers receive mandatory education during the period in which they are in Japan.

In practice, the national government's obtuse attitude towards any revision in official immigration policy seems to preempt any of the above immigration policy recommendations. Discussions revolving around the issue of immigration at the national level in Japan are typically based on the lack of widespread acceptance owing to Japan's perceived lack of any significant historical experience with immigration, arguments that defend a closed immigration policy are related to racial and cultural homogeneity, the perceived relationship between larger numbers of foreigners and increases in crime, and most recently, terrorism (Murphy-Shigematsu et al., 2006). Used singularly or in any combination, arguments related to immigration rarely reach the steps of the DIET, let alone into the DIET as politicians continue to block progressive immigration reform.

\section{History of Immigration}

Voices against immigration have continued to use the argument that Japan has no history of accepting immigrants and that immigration would be a disruptive force. ${ }^{6}$ Indeed, it would not be untrue to say that Japan has not experienced the kind of massive immigration into her borders that many Western countries have experienced. However, if we look closer at the origin of some $24.1 \%$ of the registered foreigners

5 Old Comers refers the collection of foreigners that have resided in Japan for several generations. These individuals included Chinese, Koreans and Taiwanese who either migrated to Japan when their countries formed part of the Japanese Empire, or they are individuals that were forced to come to Japan to work in factories and heavy industry during Japan's war efforts. See Kashizawaki (2003) Local Government and Resident Foreigners: A Changing Relationship, in Shunichi Furukawa \& Toshihiro Menju Eds., International Policies of Local Governments: Japan's Role to Pluralism-Transforming Local Communities in the Global Era, Tokyo, Japan Center for International Exchange, pp. 65-66.

6 The Basic Plan for Immigration Control (The $2^{\text {nd }}$ edition) I Introduction - Social changes and immigration control: http://www.moj.go.jp/ENGLISH/information/bpic2nd-01.html (Accessed June 15 ${ }^{\text {th }}, 2006$ ). 
living and working (a figure that is approximately 600,000) in Japan today, ${ }^{7}$ we can trace their origins back to Taiwan, China and Korea a time when the Japanese government allowed free movement between the outer areas of the Japanese Empire to the inner areas of the Japanese Empire for work or family related reasons (See Figure 1) (Hirano, 1984).

Figure 1 : Changes in the number of foreign nationals from 1955 to 2006 and its percentage of the total Japanese population

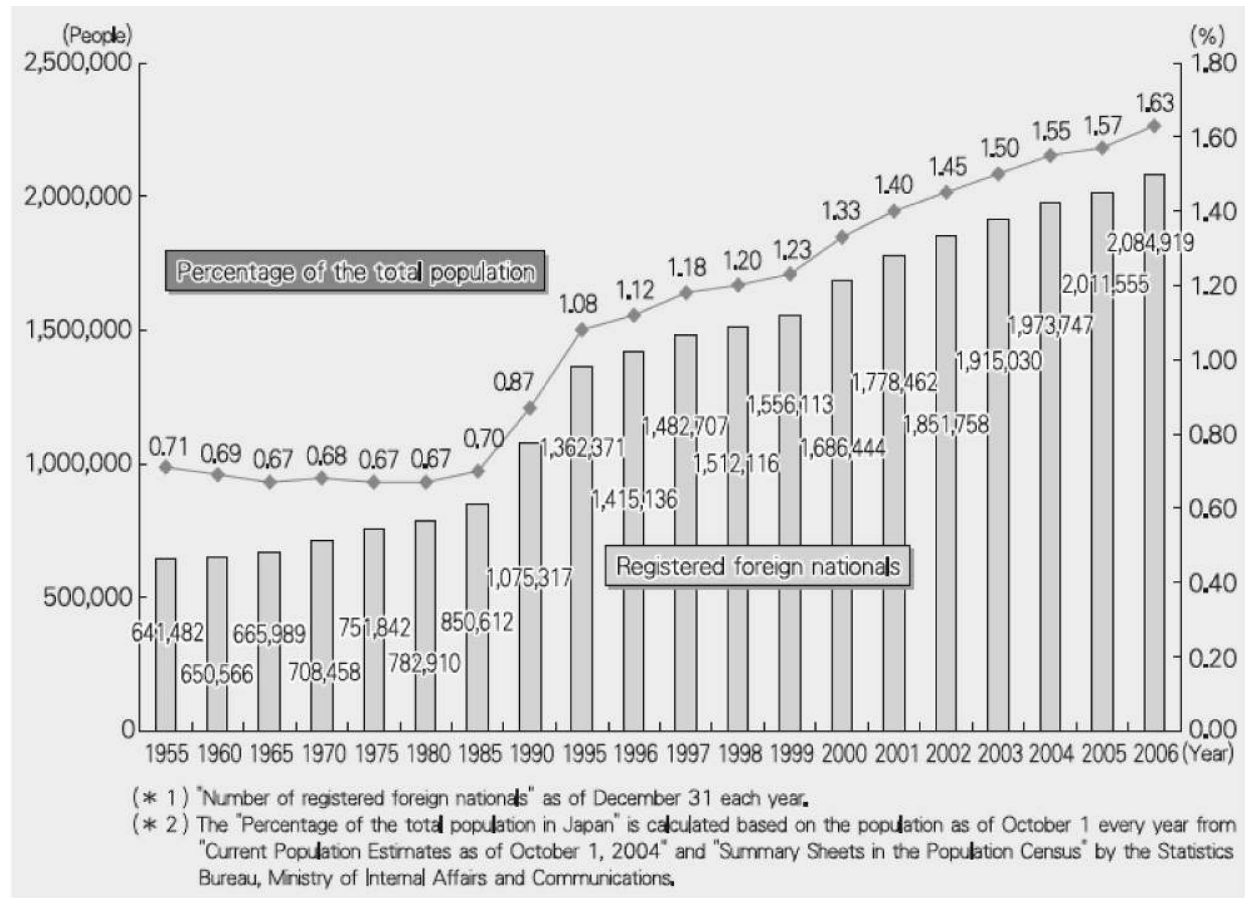

Source : “2007 Immigration Control,” Immigration Control Bureau, Japan, 2008, p. 19.

7 According to the Ministry of Justice, between the end of the war and 1965, the number of registered foreign nationals residing in Japan remained between 550,000 and 650,000. Special permanent residents, mainly comprised of Korean nationals accounted for nearly $90 \%$ of the total. Since the late 1960 s, the number of special permanent residents has decreased, while the number of foreign nationals coming to stay in Japan for various purposes has increased. An increasing number of foreign nationals have been living in Japan for a medium-length or long time. See "Basic Plan for Immigration Control", $3^{\text {rd }}$ Edition:

http://www.moj.go.jp/ENGLISH/information/bpic3rd-02.html\#2.htm (Accessed January $15^{\text {th }}$, 2006). 
Japan practiced a relatively open policy emigration policies from the end of WW II to the 1970 (Befu, 2001: 10-35). In fact, the Japanese government actively encouraged internal migration and emigration abroad because of high unemployment and a strong desire to rebuild Japan's tattered economy. Then, as Japan's economy transformed itself into an economic giant, and the manufacturing industry and the economy as a whole demanded more workers, the government began to discourage immigration. To compensate for the need for factory workers, the Japanese government began to encourage migration within Japan, recruiting young men, and women to a certain degree, from the countryside.

Initially, internal migration met the industrial needs of this period accounting for no immigration from abroad. However, young Japanese began to shun the manufacturing industry and other blue collar jobs, choosing white collar employment for its status, financial rewards and an aversion for work characterised by the three Ks, that is kitanai/污い, kitsui/きつい, kiken/危険 (dirty, difficult and dangerous respectively). These trends eventually led to the dilemma of how to ensure the engines of economic growth would keep moving with a paucity of workers. The solution was simple; Japan needed to import foreign workers to work in the manufacturing industry. Hence, foreigners began to percolate into Japan as migrant labourers, both legally and illegally.

In the 1980s, the explosive economic growth of the Bubble Economy acted as a beacon for migrant labourers. This dilemma was compounded by the appreciation of the Japanese Yen following the September 1985 Plaza Agreement ${ }^{8}$ and the first Gulf War which made Japan an even more attractive destination for economic migrants (Tegtmeyer-Pak, 1998: 37). Japan was seen as a country that was stable, safe and a land where migrants could easily earn Yen resulting in large numbers of foreigners both legally and illegally making their way to Japan. Young Japanese continued to shun manufacturing industries in favour of the riches to be found in the booming, bustling cities proliferating the need for blue collar labourers. The conditions of the bubble economy had wide effects on Japan as a whole. The large influx increase of foreigners, especially of the unskilled variety was accompanied by a troika of trends: a decreased number of 18 year olds available to the labour market, an increased number of 18 year olds going on to college or university and an increased number of youth not wanting to work in jobs associated with the $3 \mathrm{Ks}$ (Befu, 2000: 3-5). Furthermore, there was an explosion in the number of NGOs that were dedicated to combating the injustices directed against foreigners, especially illegal foreigners (Menju, 2003: 96-97). These

8 http://www.g7.utoronto.ca/finance/fm850922.htm (Accessed July $21^{\text {st }}, 2006$ ).

Plaza Agreement: An agreement reached in September 1985 by the G-5 countries (France, West Germany, Japan, the UK and US), on a need to adjust current exchange rates. The governments of these countries agreed that the \$US was overvalued, lectured foreignexchange markets about the need to take account of economic fundamentals and directed markets to bring the \$US down. They made plain their intention to intervene if necessary. http://www.anz.com/edna/dictionary.asp?action=content $\&$ content=plaza_agreement (Accessed July $21^{\text {st }}, 2006$ ). 
NGOs assisted migrant workers including Indochinese refugees from Vietnamese, Laotians and Cambodians with Japanese language classrooms, a multitude of advisory services, and in setting up exchange events in the local community. ${ }^{9}$

Following the collapse of the economic bubble and the commencement of the so-called "Lost Decade," the increase in foreign migrants continued unabated. In 1991, the Japanese government revised the Immigration Control and Refugee Certification Act to allow those of Japanese ancestry (up to third generation) to work freely and unobstructed in Japan (Beju, 2000: 3-5). As a consequence, the 1990s were marked by an influx of South Americans with Japanese ancestry who eventually settled in several manufacturing districts (Menju, 2003: 22-23).

Japanese historian Kanji Nishio, being one of the most prominent voices against immigration based on Japan having any history of accepting immigrants, cites that open immigration would create a marginalised class of foreigners because of irreconcilable cultural and linguistic differences. ${ }^{10}$ In many ways his comments are echoed by fellow scholars studying Brazilian Japanese communities who have shown that marginalisation takes the form of $28 \%$ of foreigner migrants not receiving any kind of medical health insurance (Kojima, 2006). Studies beginning in 1985 by local governments have also shown that foreign residents have challenges in the areas of education, living conditions as well as others. ${ }^{11}$

In his comparative study of the incoming earning differences between Japanese Brazilian migrants and native Japanese, Hirohisa Takenoshita of Shizuoka University demonstrated that there is indeed economic disparity between these two groups. ${ }^{12}$ Not withstanding this difference, Takenoshita's analysis fails to mention that depending on the foreigner group, economic disparities may differ. In the case of Brazilian-Japanese, income differences can be explained by the fact that the majority of Brazilian Japanese work in the manufacturing industry and that a lack of language proficiency, especially in reading and writing, which prevents this group of foreigners

9 Kanagawa Kennai Zaiju Gaikokujin Jittai Chosa Iinkai (Kanagawa Prefecture Committee for the Investigation of Prefectural Foreign Residents) (1985) Kanagawa Kennai Zaiju Gaikokujin Jittai Chosa Hokokusho: Kankokujin, Chosenjin, Chugokujin ni tsuite (Report on the Investigation of Foreign Residents in Kanagawa Prefecture: Koreans, North Koreans and Chinese Residents). Kanagawa.

10 NISHIO Kanji (1989) Rodou Sakoku no Susume: Gaikokujin Rodousha ga Nihon o Horobosu (Recommending a "Closed Country to Labour": Foreign labourers will destroy Japan), Tokyo: Kobunsha. 1989, pp. 13-73; Kanji, Nishio. "The Danger of an Open-Door Policy." Japan Echo17, No.1 (1990): p. 51-56.

11 Kanagawa Kennai Zaiju Gaikokujin Jittai Chousa Iinkai. (Kanagawa Prefecture Committee for the Investigation of Prefectural Foreign Residents) (1985) Kanagawa Kennai Zaiju Gaikokujin Jittai Chousa Kekka Gaiyo: Gaikoku Kenmin to tomo ni Ikiru tame ni (Outline of the results from the Investigation of Foreign Residents in Kanagawa: Living together with Prefectural Foreign Residents), Kanagawa.

12 TAKENOSHITA Hirohisa (2006) Gender, Ethnicity, and Economic Disparity: A Comparative Study of Income Earnings between Japanese-Brazilian Migrants and Native Japanese, The Japanese Journal of Population, 4 (1), pp. 56-77. 
from overcoming this income gap. Similar figures can be found in Canada, France and England in which language barriers create economic disparity between natives and new immigrant's migrant (Usui, 2006). Also, Takenoshita neglects to take into account that different nationalities work in different sectors of the economy, such as the financial sector, that could result in reverse economic disparity. This data demonstrates that arguments against immigration based on the desire to not create economic disparity are not baseless or uniquely Japanese problems. Other nations have shown themselves to be adept in overcoming these problems in whole or in part.

In reality, various ethnic groups fill the needs of the various sectors of the Japanese economy. For example, Nikkeijin's originating from South America are prominent in the manufacturing hubs located in Shizuoka, Gunma and Aiichi prefectures (Usui, 2006). Language and educational levels hinder their career path as opposed to organisational discrimination or a deliberate effort to marginalize the Nikkeijin population.

According to the 2005 Current Statistics on Registered Foreigners, Chinese represent $73.9 \%$ of the "trainee" positions followed by Indonesia, Vietnam, Philippines and Thailand totaling $96.2 \%$ of all trainee positions, ${ }^{13}$ while old comers are found in most sectors of the economy. In the former case, language barriers have been overcome through language training and educational background. Special skills in the areas of technology, engineering and other fields also allow this group of foreigners to be anything but marginalised. The latter group, on the other hand, with its cultural and linguistic abilities is able to access Japanese society and work in sectors of the economy in newcomers may find difficulty to find entry points owing to their temporary nature (Suzuki, 2004).

Most Westerners can be found in educational related fields, big business and finance industries (Komai, 2001: 89-90). Probable explanations for this concentration are that few foreigners who originate from Western countries are economic migrants. Also, comparatively, there are still only small numbers of Westerners studying at Japanese universities and as a result few Westerners with the language skills and cultural savvy to join trainee programs and work in Japanese companies.

The increased numbers of illegal migrants, or as Komai calls them, irregular workers, is increasing in concentration in Tokyo and is connected to a shift away from the construction industry and manufacturing and into the service industry (Komai, 2001: 89-90).

13 See Kokuseki - Shushin Chiiki Betsu oyobi Zairyu Shikaku Betsu Koka Jimin (Chart on Employees with Permission to Work by Nationality and Region) http://www.moj.go.jp/ (Accessed June $15^{\text {th }}$, 2006); Houmusho (Ministry of Justice) (2005) Heisei 16 Nenmatsu Genzai ni okeru Gaikokujin Torosha Tokei ni tuite(2005 Current Statistics on Registered Foreigners), Tokyo: Houmusho (Ministry of Justice) http://www.moj.go.jp/PRESS/050617-1/050617-1-1.pdf (Accessed June 15 ${ }^{\text {th }}$, 2006). 
Similarly, we have also seen ministries express their aversion to immigration. The Ministry of Health, Welfare and Labour worries that low paid foreign workers will come to occupy jobs that no Japanese would be interested in (Tegmeyer-Pak, 1998: 35$38)$.

In practice the national government has demonstrated its commitment to a non-immigration policy with its continued recalcitrant attitude to signing international conventions and treaties that protect the rights of migrant workers and thus prevent them from settling long term since their rights are neither secured nor protected. For example, Japan has failed to ratify the "International Convention on the Protection of All Migrant Workers and Members of Their Families," which focuses on irregular and regular migrant workers emphasizing equal treatment of migrant workers and nationals in terms of working conditions and social security (Komai, 2001: 119-120). Additionally, the Japanese government remains obstinately opposed to signing International Labour conventions that protecting the rights of migrant workers. ${ }^{14}$

The question then is how exactly is immigration perceived at the national level? First of all, many law makers at the national level in Japan link immigration to widespread social unrest, including increased crime rates. Second, immigration will result in clan cleavages and stratified labor markets. Finally, immigration is seen as the seed leading to growth discrimination, human rights abuses and ethnic tension (Tegtmeyer-Pak, 1998: 95-96).

\section{Homogeneity and Crime}

Critics against a more liberal immigration policy include those who believe that immigration would disrupt Japan's cultural and racial homogeneity. Again, Kanji Nishio, one of the strongest proponents against immigration, grounds his argument on the theme of Japanese racial and cultural homogeneity. Linking Japan's economic and social success and stability to Japan's supposed ethnic homogeneity; Nishio asserts that immigration would destabilise Japan based on the rationale that different ethnic groups cannot live peacefully or equally side by side (Nishio, 1989). Citing domestic examples including ethnic tension between Chinese and Vietnamese refugees, and international examples including ethnic tensions in France between southern French people and Algerians, Nishio sketches a picture of immigration that is fraught with conflict, discrimination and strife. ${ }^{15}$

14 ILO: See No.97 adopted in 1949 \& No.147 adopted in 1982, No.97 stipulates that migrant workers should receive equal treatment to nationals in terms of working conditions, including access to public services, wages and the right to join unions, No.143: calls for granting labour rights to all migrant workers including irregular workers. No.118 adopted in 1962 calls for equal treatment for nationals and foreigners, No.157: adopted in 1982 migration should not lead to loss of benefits such as pension http://www.ilo.org/ilolex/english/convdisp1.htm (Accessed July 24 ${ }^{\text {th }}, 2006$ ).

15 "Benri dake de wa Kiken/ Takoku no Kyoukun Shiro ("Convenient but dangerous, Against a Multinational Country"), Mainichi Yomuri, June $14^{\text {th }}, 1990$. 
In a similar vein, the national government in 1991 accept the revised "Immigration Control and Refugee Certification Act" allowing those of Japanese ancestry (up to $3^{\text {rd }}$ generation) to return to Japan and work freely. Although not overtly stated, the basis for this selective revision of the immigration policy at the time was that those of Japanese ancestry would be better able to adapt and integrate into Japan because of their ancestry. It was assumed that they would be linguistically proficient and culturally savvy thus able to live and work in Japan without precipitating any kind of social disruption. Unfortunately though, social disruption in terms of crime has been one of the consequences of this policy with Nikkeijin's are second only to Chinese migrants in terms of crimes committed. ${ }^{16}$

The Basic Plan for Immigration Control ( $2^{\text {nd }}$ edition) published by the Ministry of Justice in 2000 also illustrates Japan's concerns with the influx of foreigners and their impact on the Japanese society.

If you trace back the history of Japanese society and give thought to the Japanese people's perception of society, culture and their sensitivity, it would not be realistic to suddenly introduce a large number of foreign labour. Rather, it is necessary for Japan to aim at maintaining the vitality of the socio-economy and enhancing tangible and intangible affluence of social life by accepting foreigners in a way that would cause little friction with society. We should solve the problems step by step; the scope of acceptance (In which fields do we like to accept foreigners?), the conditions (What experience or background should foreigners have in order for Japanese people to live together with them in harmony?), and the treatment (What social-life environment can we offer to the foreigners once they are accepted? ). ${ }^{17}$

Here we see the Ministry of Justice linking foreign labour to social stability based on the Japanese people's perceptions of society and culture. The essence of the viewpoint is that the homogeneous nature of Japanese society requires and immigration policies that are selective, accepting foreigners that will coexist with Japanese, causing little friction while at the same time contribute to the socio-economic vitality of Japan. Interestingly, the Ministry of Justice's statement alludes to coexistence rather than full fledged immigration or naturalisation hinting at a policy that will remain exclusive.

16 The National Police Agency publishes annual report breaking down crime rates into demographics. Statistic breakdown incidents dealing with police into "crimes" and "offenses". The former includes violent incidents while the later includes visa infractions, speeding and prostitution. From these statistics we can see that the crimes committed by foreigners on the whole are lower than Japanese except for foreigners that originate from South America (on the whole Nikkeijin, legally living and working in Japan). http://www.npa.go.jp/kokusai2/15b/siryo.pdf (Accessed August $2^{\text {nd }}, 2006$ ).

17 Quote from the Ministry of Justice's The Basic Plan for Immigration Control (The $2^{\text {nd }}$ edition) I Introduction - Social changes and immigration control http://www.moj.go.jp/ENGLISH/information/bpic2nd-01.html (Accessed June 15 ${ }^{\text {th }}, 2006$ ). 
Not withstanding the recommendations put forward by the Report on the Future Acceptance of Foreigners, national immigration policy still remains closed, ${ }^{18}$ adhering to the following fundamental principles of accepting no unskilled workers to Japan (with the exception of Nikkeijin), the admission of only highly skilled and professional foreign workers and the admission of foreign workers as non permanent workers (Tsuda, 2006: 13-14). These policies are a consequence of ministries that continue to create policy based on assumptions related to cultural and racial homogeneity.

Rising criminal acts committed by foreigners are also often cited as one of the explanations for Japan's restrictive immigration policies. In reality, researchers such as Hashimoto Kohei have shown that crime rates among foreigners over the past 30 years have decreased (Hashimoto, 1994). In a similar vein the National Police Agency has published data clearly indicating that particular groups of foreigners are more likely than others to commit crimes and offences. ${ }^{19}$ Both Hashimoto's data and the NPA's data run counter to the national government's argument against increasing immigration levels based on the expectation of increased crime rates by incoming immigrants. Still, despite official figures demonstrating that crime rates have decreased and that crimes by foreigners are less than Japanese nationals the national government still continues to use this argument.

\section{LOCAL GOVERNMENTS}

Local governments in Japan are tasked with the responsibility of providing social welfare programmes, education, local law enforcement as well as a host of other responsibilities that are designed to meet the immediate needs of their residents. Furthermore, since 1986, wards have been entrusted with a changing set of responsibilities, when local governments were authorised to establish International Exchange Sections and International Exchange Associations by the Ministry of Home Affairs (MOHA) (Menju, 2003: 34-35). At this time, MOHA emphasised that local governments focus their international endeavours on sister city relationships, providing information about Japan overseas, cultural events and international festivals, assistance to small export companies, home-stay programmes and other types of "cultural diplomacy" (Purnendra, 1993). In 1989, the "Plan on the Promotion of Local International Exchange Policies" was promulgated by the MOHA which focused on distributing the responsibilities for activities that fall under the rubric of local Internationalisation thus making the International Exchange Association the central pillar of International Exchange. The plan also highlighted the necessity of creating

18 Gaikokuseki Kenmin Kanagawa Kaigi Dainiki (The Second Meeting of Foreign National Residents of Kanagawa Prefecture) (2002). Tabunka Kyousei Shakai Kanagawa no Jitsugen ni Mukate: Saishu Hokokusho (Towards realising a Multicultural Coexistence Society in Kanagawa: First Report), Kanagawa.

19 See National Policy Agency http://www.npa.go.jp/kokusai2/15b/siryo.pdf (Accessed August $\left.2^{\text {nd }}, 2006\right)$. 
local cities in which foreigners could participate actively. Since 1986, Internationalisation thinking has progressed from cultural exchange in the 1980s, International Cooperation in the 1990s to multicultural co-existence in the 2000s.

At the national government level, immigration as illustrated above is a nonissue. Japan still remains a country closed to immigration (Suzuki, 2004). Foreigners that have the appropriate work visa can enter Japan freely and, as of recently, can receive social welfare assistance while illegal residents cannot. The shoulder of the burden for the problems of foreigners has fallen squarely on local governments owing to the fact that local governments are the immediate interface with residents and the second window into Japan following immigration at airports or seaports. Local governments have become the immediate interface with all foreign residents living in their boundaries owing to the "Foreigner's Registration Act" which requires local governments to register all foreign residents. ${ }^{20}$

In addition to the Foreigner's Registration Act being so influential in contributing to the role of local governments in issues related to foreigners, MacDougall asserts that legal responsibilities and proximity to residents has forced the burden of dealing with the needs of foreign residents upon local governments (Komai, 1997; Susumu, 1992, McDougall, 2001). Also, the history of local progressive governments and independent policy making as exemplified by Kanagawa Governor Kazuji Nagasu has created an atmosphere of independence to pursue policy that reflects local needs (Muramatsu, 1997; Nagasu, 1983). Finally, we have seen the catch word of Internationalisation be redefined to include the assistance of foreigners, international exchange and most recently multicultural coexistence with foreign residents. ${ }^{21}$

Legally, all foreigners who stay in Japan for more than 90 days must register at the local municipal office where they are living. Upon registration they will receive a foreigner's registration card indicating their place of living, place of employment, visa status and expiry date. The foreign registration card acts in lieu of one's passport as identification and as an essential piece of identification when registering for the aforementioned social welfare programmes, renting an apartment and entering/leaving the country.

Foreigners that come to live and work in Japan without proper visa certification cannot get a foreign registration card and subsequently cannot benefit from the social welfare programmes whether they need to or not. Furthermore, foreign residents,

20 See Ministry of Justice: http://www.moj.go.jp/ENGLISH/IB/ib-01.html (Accessed July $23^{\text {th }}$, 2006).

21 Tokyo Kokusai Kouryu Dantai Renraku Kaigi (Tokyo International Communications Association) (2005) Tokyo Kokusai Kouryu Dantai Renraku Kaigi Dairekutori- (Tokyo International Communications Associations Directory), Tokyo; Also see: Lifestyle and Cultural Bureau of the Tokyo Metropolitan Government (2000) The 2000 Report on the "Current Situation of International Policies of Wards, Cities, Towns and Villages in the Tokyo Metropolitan, Tokyo, Lifestyle and Cultural Bureau of the Tokyo Metropolitan Government. 
but especially illegal foreign residents, still do not enjoy rights and privileges such as basic human rights, housing, employment, education, medical services, citizenship and importantly a relationship with the majority of society. ${ }^{22}$

Over the years local governments have attempted to overcome the problem of rights for their foreign residents in several ways. First, based on Local Government Law, those living in their boundaries of a particular municipality are considered residents (Komai, 2001). Residents, no matter their nationality are entitled to the services that the local government provides. What can be said is that local governments across Japan are reacting to the gap left by the national government vis-à-vis foreign residents through Domestic Internationalisation ${ }^{23}$ policies using concepts of citizenry found Local Government Law. Initiatives included in these policies vary depending on the local needs of each local government.

Domestic Internationalisation policies are interesting because they provide numerous examples of local policy targeted at foreign residents that is counter to the national policy such as setting up multilingual advisory services, encouraging the enrolment in all social service programmes, providing monthly information bulletins with information on vaccinations, school enrolment, the steps to enroll in National Health Care, Social Insurance and a host of others. ${ }^{24}$ Another example includes the local governments in Kawasaki, Osaka and Kyoto granting all foreigners (not only foreign permanent residents) the right to hold public sector jobs including managerial positions, despite opposition from the Ministry of Home Affairs( today known as the Ministry of Internal Affairs and Communications). ${ }^{25}$

As previously mentioned, local governments are the closest government administrative apparatus to ordinary residents. They are responsible for enrolment in schools, registering and distributing national health care, pensions, child subsidies, registering births, the distribution centres for social welfare programmes. By virtue of these administrative functions local governments are the immediate interface between local residents and government. Importantly, local governments have also been

22 Children are generally an exception to this overt discrimination, As the International Relations Coordinator at Itabashi City Hall for 4 years I worked with, interpreted and translated for families who were illegal residents but wanted to enroll their children in local schools. In practice, children without reservation were enrolled in programs. Financial subsidies which required income statements were not dispensed to families in need.

23 Domestic Internationalisation is defined as policies planned and instituted by local governments that are promoting a more inclusive society such as Gaikokujin to no Kyousei Shakai (Social coexistence with foreign residents). See Nagy, S.R. "Understanding "Internationalization" within the Context of Japan". Journal of the Graduate School of AsiaPacific Studies. Waseda University. (September 2006).

24 For an example of one local governments monthly publication see: http://www.city.itabashi.tokyo.jp/icief/iciefboard/index_e.html (Accessed July $25^{\text {th }}$, 2006).

25 Some wards in the Tokyo Metropolitan area have also established full and part-time positions for foreigner residents in their administrative apparatus. The author himself worked for 4 years in Itabashi Ward's International Exchange Section in the Tokyo Metropolitan Area. Also see: Komai 2001: 131. 
entrusted under the Foreigner Registration Law to register foreign residents who reside in Japan for more than 90 days at a local government's Foreigner Registration reception window.

Both the Local Government Law and the Foreign Registration Law have impacted local governments, compelling them on the one hand to plan and implement Domestic Internationalisation policy, attempting to create a more inclusive society, while on the other hand, these laws have "trapped" local governments in that they cannot but create these inclusive policies because of the lack of involvement at the national level. However, Local Government Law has allowed progressive policy development with autonomy (the direct translation of the Japanese Jichitai is local autonomous government). Legally being responsible for the health, safety and welfare of all residents has enabled local governments to innovatively create policy that reflects the needs of their community. ${ }^{26}$

Local governments across Japan thus have been compelled to create integrative, inclusive policies because of three of factors; first, the Local Government Law, second the Foreigners Registration Law and finally the national government's lack of any integration policy.

At the local government level, inclusionary policy has taken many forms and is neither comprehensive nor unified across Japan. For example, as previously mentioned the municipalities of Kawasaki, Kyoto and Osaka have granted foreigner residents the right to work in managerial positions in local governments. Kawasaki City has created a foreigner resident advisory council with elected representatives and opportunities to voice concerns and proposals to the local chamber of councilors. ${ }^{27}$ Other municipalities such as Tachikawa City, in the western suburbs of Tokyo, and the Shinjuku and Bunkyo Wards have organised committees to research, plan and implement Tabunka Kyousei (multicultural coexistence) policy. Inclusionary policy although in no way is it complete because it has not broached the idea of voting rights for resident foreigners.

The momentum behind inclusion policies in municipalities across Japan is not uniform. Rather, what we see is city and ward specific policies geared to the local

26 Shinjuku Ward, found in the heart of the Tokyo Metropolis embodies this independent policy direction. With a foreign population of nearly $10 \%$, Shinjuku has the most diverse foreign demographics of all the wards of the Tokyo Metropolis as well as the largest population of foreign residents. These facts have led to the development of a Multicultural Coexistence plan that has been implemented. Similar plans have been developed in Kawasaki City and Tachikawa City in the Tokyo area.

27 "Jichitai ni okeru Chiiki ga Ichidai to Natte Kokusaika he no Torigumi: Gaikokujin no Sumiyasui Machi Nihonjin mo Yasui-Tabunka Kyousei Shakai o Mezasu Kawasaki Shi Jisaku-(The first step in internationalisation at the local government level: Kawasaki City Measures for a society that is easy to live in for foreign residents and Japanese residents)", Jichitai Fo-ramu (Local Government Forum). Zaidan Honin Jichitai Kokusaika Kyokai (International Association), Vol.191, No.9, 2005. 
needs of the community. In some communities where the foreign population is low or insignificant we see little if any emphasis on inclusion. In other communities, the number of foreign residents coming from Asia is quite large and inclusion policies are accordingly adjusted. Still other communities have diverse foreign demographics thus again requiring a different kind of policy.

Local governments have not developed inclusion policy/Domestic Internationalisation policy in a vacuum, quite the contrary; it was developed through a complex web of interactions between old comers, newcomers and local Japanese citizen groups. Moreover, as illustrated above, policy development has been in part a reaction to the inaction of the national government as well as pressure stemming from the responsibilities and obligations of international treaties and local law.

\section{Old Comers}

Old comers have been instrumental in the push towards greater inclusivity in Japan. Striving for equality under the law since the end of WW II, Old Comers have organised themselves, demanding equal rights according to Treaties of Reciprocity. ${ }^{28}$ It wasn't until the early 1980's in fact when long term residents were legally able to receive national health insurance, social welfare and pension programme (Komai, 2001: 17). These groups of foreign residents have organised themselves into different types of groups vocalising their concerns and needs to local governments. Examples of such groups include the Association of Nikkei and Japanese Abroad those who are active in ensuring that their rights are secured, that mother tongues are preserved and that issues related to discrimination are resolved immediately. ${ }^{29}$ Old comers, being long time residents are not hampered by linguistic or cultural misunderstandings thus inclusionary policies that target old comers are mostly associated with equal and fair access to social welfare systems. In short, inclusionary policies attempt to remove structural obstacles that interfere with the realisation of the right to basic human rights, and resident rights.

New Comers

New Comers on the other hand, have been pivotal in influencing local government domestic policy in that they are the immediate benefactors of inclusionary policy. This group of foreigners is generally linguistically and culturally disadvantaged.

28 Yano, in his work entitled "Nihon no Kokusai o Kangaeru (Thinking about Japan's internationalisation)" describes the outright discrimination faced by old comers when in fact Americans living and working in Japan were guaranteed based on Treaties of Reciprocity access to basic health care, safety and social welfare programmes. Not until 1965 did old comers begin their initiatives to realize their rights for social welfare under treaties of reciprocity. See YANO Toru (1988) Nihon no Kokusaika o Kangaeru: Kokusaika to wa Nani Ka (Thinking about Japan's internationalisation: What is internationalisation?), Tokyo: Nikkan Kogyo Shinbunsha, pp. 23-25.

29 http://www.jadesas.or.jp/index-en.html (Accessed July 29 ${ }^{\text {th }}, 2006$ ). 
Most do not have a firm grasp of Japanese (especially in the skills which are necessary to function in a Japanese work environment) creating extreme difficulties when trying to find employment, accessing basic social welfare programmes, health care, pensions, understanding Japanese social obligations such as laws, customs etc. Inclusionary policies target new comers in a much different manner than old comers, because of their need. Linguistic and cultural hurdles prevent new comers from accessing social welfare programmes but also provide significant obstacles to contributing to Japanese society according to their obligations as residents such as obeying laws, paying taxes etc. Moreover, the same linguistic and cultural obstacles have created a sort of humanitarian crisis, with a segment of the foreigner resident population unable to receive basic health care and other social welfare not because of a lack of need, rather they are unable to receive these services and amenities because they can't communicate or don't understand or have the information to understand how and where to receive these services. In the newcomers case, inclusionary policies by local governments attempt to overcome this hurdle by providing multilingual guide books, setting up advisory reception windows and free multilingual legal counseling. ${ }^{30}$ Other programmes include Japanese language training, guided tours and explanations on how to dispose of rubbish, translation and interpretation services, work introduction services, ${ }^{31}$ and information on medical institutions and clinics that can provide services in foreign languages. ${ }^{32}$

\section{Local Citizen Groups}

Local citizen groups were initially established in the 1960s as a means to return to international society and recovery from the devastation of WWII (Menju, 2003: 92-98). This expanded into initiatives for Bangladeshi's in the 1970s following their independence, followed by a huge increase in both the number and variety of local citizen groups involved in aiding, assisting and providing support to refugees from Indochina (Menju, 2003; Hirano, 2005: 81-82).

As the number of foreigners legally or illegally coming to Japan continued to increase, there was a realisation by local citizen groups and local governments that the needs of foreign residents were not being met. As a consequence, the initial forays by local citizen groups into the realm of inclusivity based activities has developed into several kinds of relationships with local governments related to the 1988 Kokusai

30 New comer oriented policies have manifested themselves into many kinds of services, information and programs that contribute to overcoming language and cultural obstacles. For example, within the Tokyo Metropolis a legal advisory service called the Tokyo Relay has been organized. In collaboration with local governments throughout the TMA and the Japan Lawyers association as well as local language volunteers, a rotating free legal advisory service is offered to all foreign residents (legal and illegal residents). Included in the advisory service is free legal advise in several areas including immigration, labor related matters, divorce as well as others. Volunteer interpreters interview participating foreigners, identify the area of law in which they need counsel and then act as an interpreter for the foreign resident during their discussions with the attending lawyer.

31 See Hello Work web site http://www.hellowork.go.jp/ (Accessed July 31 ${ }^{\text {st }}$, 2006).

32 See Himawari for multilingual information on Tokyo Metropolitan Medical Institutions http://www.himawari.metro.tokyo.jp/qq/qq13enmnlt.asp (Accessed July 31 ${ }^{\text {st }}$, 2006). 
Kouryu no Machi Tsukuri no tame Hoshin (Plan on creating an International Exchange City) in which the Ministry of Home Affairs advocated the establishment of associations with the purpose of creating cities that had international exchange (Menju, 2003: 34-35).

The basic direction of the plan recognised that local society need to be designed to include the perspective of foreigners so that cities are easy to live in, be active in and engage in friendly relations. It also stated that when designing cities, designers should bear in mind that cities should by easy to live in for Japanese and for foreigners. Through the development of facilities that included foreign language bulletin boards, foreign language publications and locations in which exchanges can take place between Japanese and foreign residents, local governments were attempting to create municipalities that were more accessible. ${ }^{33}$

A key development in this process was cooperation with local citizen groups to assist in local government supported Japanese language classrooms for foreigners, to act as volunteer interpreters and translators, to organise exchange events for foreign residents, and to provide information to foreigners related to life and living in Japan.

Interestingly, local citizen groups initially became actors in integrative activities for foreigners living in Japan as a result of their own organization and initiative. Their activities were focused on small groups of foreigners from specific countries and there was no collaboration with local government. This independent relationship gradually expanded to activities that were in cooperation with local government and could be interpreted as broader integrative activities that complemented local government needs. By virtue of local citizen groups working with foreign residents in various capacities, they have contributed to integration policy development at local governments by being both the voice of foreigners as well as the initiator of new integrative measures.

\section{CONCLUSION}

At present, national immigration policy and local government integration policy continues be uncomplimentary. On the one hand, national immigration policies continue to remain closed and inflexible in terms of its liberalisation. Opening the doors for foreigners to come and work in Japan remains negotiable, however, only on a temporary basis or highly restrictive conditions. Current immigrant policy still reflects Japan's aversion to creating a more pluralistic society based on arguments associated with social stability, history and the fear of rising crime rates. In practice, Japan continues to avoid the entanglement of international conventions that will ensure the rights of migrants within her borders.

33 Soumusho (Ministry of Internal Affairs and Communications) 2006. Tabunka Kyousei no Suishin ni Kan suru Kenkyukai: Chiiki ni Okeru Tabunka Kyousei no Suishin ni Mukete (Research report on the promotion of multicultural coexistence: Towards the promotion of multicultural coexistence at the local government level), Tokyo. 
Local governments on the other hand, continue to make their municipalities more and more inclusive. Some local governments like Kawasaki City have established the Kawasaki City Representative Assembly for Foreign Residents, ${ }^{34}$ to ensure that foreign residents have a voice to express their concerns. Most local governments have established some form of International Office to act as a venue in which multilingual information can be distributed, interpretation and translation services are offered, advisory services related to local administration are offered, and language courses provided. These offices are also active in cooperative programmes with local citizen groups striving to integrate foreign residents into their local communities.

We are left with the conundrum of whether or not the disconnect between national government immigration policy and local government integration will ever be bridged? The reality is that globalisation has had broad and diverse effects on all nations including Japan. Significant effects include increased interdependence between nations in the realms of economics, politics and security. As a consequence of economic interdependence and the need for labour to meet the demands of more competitive markets, nations around the world including Japan have been compelled to either have an official immigration policy, or accept migrant labourers since nations receive "substantial benefit from immigration (migration) in terms of economic growth, demographic revitalisation, and maintenance of international status and influence" (Huntington, 2004: 180). This is exacerbated in Japan's case because of its greying population and its low birth rate. If Japan would like to retain its current economic standing, quality of life and socio-economic vitality, true immigration reform is a necessity, not a choice.

Avoiding problems associated with more open immigration will have to include cooperation with local governments in terms of developing integrative policies, but only in a limited capacity. Local governments are much better suited for the development of local integration policy simply because of proximity; they know the needs and wants of their communities. Where the national government can be helpful is by first securing the rights of foreigners by signing international conventions. Second, by providing funding for Japanese as a second language for foreigners working in Japan, the national government can share some of the financial burden local governments are shouldering to integrate foreign residents. Third, the national government needs to mobilise already pre-existing organisations, communities and foreign resident leaders to act as a bridge between Japan and foreign countries.

34 http://www.city.kawasaki.jp/25/25zinken/home/gaikoku/assembly/index.htm (Accessed July $\left.30^{\text {th }}, 2006\right)$. 


\section{References}

BEFU Harumi (2000) Conditions of Living Together, in John S. Eades et al., Eds., Globalization and Social Change in Contemporary Japan, Melbourne, Trans Pacific Press, pp. 14-21.

BEFU Harumi (2001) Hegemony of Homogeneity: An Anthropological Analysis of "Nihonjinron", Melbourne, Trans Pacific Press, pp. 68-70.

BEFU Harumi (2006), Conditions of Living Together (Kyousei), in Soo im LEE, Stephen MURPHY-SHIGEMATSU \& Harumi BEFU Eds., Japan's diversity dilemmas: ethnicity, citizenship, and education, New York, Universe, Inc., pp. 47-74.

HASHIMOTO Kohei (1994) Zainichi Imin, Rodousha no Hanzai to Sono Suii. Kenkyu Repoto(Criminal statistics on migrants and labourers to Japan Research Report), Tokyo, PHP Research Institute, Inc., Research Division, Vol. VIII, June.

HIRANO Kenichiro (1984) Kokusai Kankei ni okeru Bunka Kouryu (Cultural Exchange in International Relations), in Saito Sugiyama et al., Eds. Kokusai Kankei ni okeru Bunka Kouryu (Cultural Exchange in International Relations), Tokyo, Nihon Kokusai Mondai Kenkyujo (Japan International Global Research Institute), pp. 1-21.

HIRANO Kenichiro (2005) Sengo Nihon ni okeru "Shinmin shakai no Tenkai to Kokusai Bunka Kouryu-Gensetsu to Jittai" (The transformation of civil society and international culture exchange, limits and reality in Post WW II Japan), in Kenichiro Hirano Ed., Sengo Nihon no Kokusai Bunka Kouryu (International Culture Exchange in Post WW II Japan), Tokyo, Keisoshobo, pp. 87-97.

HUNTINGTON Samuel P. (2004), Who we Are? The Challenges to American Identity, New York: Simon and Schuster, p. 180.

KANJI Nishio (1990) The Danger of an Open-Door Policy, Japan Echo17, No.1, pp. 51-56.

KOJIMA Hiroshi (2006) Foreign Workers and Health Insurance in Japan: The case of Japanese Brazilians, The Japanese Journal of Population, 4 (1), pp. 78-92.

KOMAI H. (1997) Hajime ni- Uchi naru Kokusaika ni yoru Tabunka Kyousei Shakai no Kochiku (Begin with building a multicultural coexistence society through internal internationalisation), in Hiroshi KOMAI and Ichiro Watado Eds., Jichitai No Gaikokujin Seisaku: Uchi naru Kokusai he no Torigumi (Local Government Foreign Resident Policy: Using internal internationalization), Tokyo, Akashi Shoten, pp. 34-46.

KOMAI Hiroshi (2001) Foreign Migrants in Contemporary Japan, Melbourne, Trans Pacific Press, pp. 16-18.

MENJU Toshihiro (2003) Kokusai Kouryu • Kokusai Kyouryoku Katsudo to wa (International Exchange and International Cooperation, in Toshihiro Menju et al. Eds, Kusa no Ne no Kokusai Kouryu to Kokusai Kaitsudo (Grassroots International Exchange and International Activities), Tokyo, Akashi Shoten, pp. 30-41.

MURAMATSU Michio (1997) Local Power in the Japanese State, Berkeley, University of California Press, pp. 65-66.

NAGASU Kazuji (1983) Jichitai no Kokusai Kouryu: Hirakarereta Chiho Wo Mezashite (Local Government International Exchange: Towards an open community), Tokyo, Gakuyoshobo, p. 16-27.

NISHIO Kanji (1989) Rodou Sakoku no Susume: Gaikokujin Rodousha ga Nihon o Horobosu (Recommending a "Closed Country to Labour": Foreign labourers will destroy Japan), Tokyo, Kobunsha, 34-44.

PURNENDRA Jain (1993) Subsidiary, Supporter, or Challenger? Local-National Relations in Japan, Local Government Studies, 19(2), pp. 264-89.

SUSUMU Takahashi (1992) The Internationalisation of Kanagawa Prefecture, in Michael Weiner \& Glenn D. HOOK Eds., The Internationalisation of Japan, Routledge, London, pp. 190- 
204; Terry McDOUGALL (2001) Towards Political Inclusiveness: The Changing Role of Local Government in Japan, The World Bank

(http://siteresources.worldbank.org/WBI/Resources/wbi37169.pdf - Accessed May 15 , 2006).

SUZUKI Eriko (2004) Tabunkaka suru Nihon wo Kangaeru: Kokkyo wo Koeta Hito no Idou ga Shinten suru naka de (Reflecting on the multiculturalisation of Japan: The development of people moving and crossing borders), in FIF Special Report No.8, Tokyo, Fujita Mirai Keiei Kenkyujo, pp. 29-39.

TAKENOSHITA Hirohisa (2006) Gender, Ethnicity, and Economic Disparity: A Comparative Study of Income Earnings between Japanese-Brazilian Migrants and Native Japanese, The Japanese Journal of Population, 4 (1), pp. 56-77.

TEGTMEYER-PAK Katherine (1998) Outsiders Moving In: Identity and Institutions in Japanese Responses to International Migration, Chicago, University of Chicago, pp. 45-51.

TSUDA Takeyuki (2006) Localities and the Struggle for Immigrant Rights, in Takeyuki Tsuda Ed., Local Citizenship in Recent Countries of Immigration: Japan in Comparative Perspective, Oxford, Lexington Books, pp. 3-36.

USUI Chikako (2006) Japan's Demographic Future and Foreign Workers, in Takeyuki Tsuda, Ed., Local Citizenship in Recent Countries of Immigration: Japan in Comparative Perspective, Oxford, Lexington Books, pp. 22-46. 


\title{
Exclusion nationale, inclusion locale : déconnexion entre politiques nationales d'immigration et politiques locales d'intégration
}

\author{
Stephen Robert NAGY
}

Le Japon est confronté au déclin de sa population, situation démographique qui menace son avenir économique. De plus en plus, les débats sur l'immigration envisagent l'installation d'étrangers comme un moyen pour compenser le tassement de la main-d'œuvre. Malgré les besoins de l'économie, le gouvernement japonais reste opposé à tout changement de sa politique restrictive, et continue à freiner les flux migratoires. Par contre des attitudes plus progressistes peuvent être observées au niveau local, où les autorités deviennent de plus en plus ouvertes, développent des politiques permettant l'inclusion des étrangers parmi les résidents. C'est cette déconnexion entre les politiques nationales d'immigration et les politiques locales d'intégration que nous examinons dans cet article.

\section{National Exclusion, Local Inclusion: Examining the Disconnect between National Immigration Policies and Local Integration Policies}

\section{Stephen Robert NAGY}

Japan is faced with a declining population, which will threaten its economic viability in the years to come. Increasingly, discussions with regards to foreigners being used to compensate for this declining workforce are occurring under the rubric of immigration. Despite the necessity for change, the Japanese government still remains closed to the idea of changing its immigration laws to adjust to economic demands, thereby stemming the influx of foreigners into Japan. However, we can see more progressive policies at the local level, where local governments are continually becoming more open, making their municipalities more inclusive for all residents. This paper will discuss this disconnect between national immigration policies and local integration policies.

\section{Exclusión nacional, inclusión local: \\ Desconexión entre políticas nacionales de inmigración y políticas locales de integración}

\section{Stephen Robert NAGY}

La población de Japón tiende a declinar, y esta situación demográfica amenaza a su porvenir económico. Es cada día más corriente que en los debates sobre la inmigración la instalación de extranjeros en el país aparezca como un medio para compensar la disminución de la mano de obra. El gobierno japonés, a pesar de las necesidades de la economía, sigue opuesto a todo cambio de su política restrictiva y frena los flujos migratorios. En cambio a nivel local las autoridades practican políticas más progresistas, más abiertas, permitiendo la inclusión de los extranjeros entre los residentes. Es esta desconexión entre políticas nacionales de inmigración y políticas locales de integración que examinamos en este texto. 
